\title{
PENGARUH METODE PEMBELAJARAN ILEARNING PADA KELAS INDEPENDENT STUDY TERHADAP PENINGKATAN KUALITAS PEMBELAJARAN DAN PENILAIAN
}

\author{
Ageng Setiani Rafika ${ }^{1}$ \\ Erick Febriyanto ${ }^{2}$ \\ Fikrah Syafa' $a h^{3}$ \\ Dosen STMIK Raharja ${ }^{1,2}$ STMIK Raharja Jurusan Teknik Informatika ${ }^{3}$ \\ Jl. Jendral Sudirman No. 40, Modern Cikokol, Tangerang \\ Email : agengsetianirafika@ raharja.info ${ }^{1)}$, erick@ raharja.info ${ }^{2)}$, fikrah@ raharja.info ${ }^{3)}$
}

\begin{abstract}
ABSTRAK
Perguruan Tinggi Raharja merupakan salah satu Perguruan Tinggi yang menerapkan suatu metode pembelajaran yang cukup berbeda yaitu tidak hanya mengandalkan sistem pembelajaran konvensional dimana KBM (Kegiatan Belajar Mengajar) dilakukan dengan cara Mahasiswa dan Dosen diharuskan bertatap muka secara langsung, melainkan juga menerapkan metode pembelajaran secara e-learning atau lebih dikenal dengan sistem pembelajaran iLearning Education di Perguruan Tinggi Raharja. Pada penerapannya digunakan beberapa perangkat yang mendukung sistem pembelajaran tersebut mulai dari iDu (iLearning Education) sebagai media interaksi Mahasiswa dan Dosen dan juga Penggunaan iLearning Media (iMe) sebagai media yang menampung aktivitas kegiatan pembelajaran melalui metode iLearning Education. Kemudian selama berjalannya metode ini beberapa pertanyaan muncul tentang seberapa validkah sistem tersebut terhadap kualitas penilaian dan efektivitas metode pembelajaran dimana dari hal ini dirasa perlu untuk diterapkan suatu alat ukur yang dapat mengukur validitas sistem terhadap kualitas dan efektivitas metode pembelajaran di Perguruan Tinggi Raharja khususnya pada kelas Independent Study IL101A dan IL101C. Dengan menggunakan metode deskriptif dengan pendekatan survey penelitian dilakukan dimana dari survey yang dilakukan didapati sebuah pemecahan masalah yaitu pengadaan suatu alat ukur yang nantinya dapat menampilkan data-data historis dengan beberapa kategori tertentu dari segi efektivitas pembelajaran dapat dibuktikan secara empiris melalui data-data yang akurat.
\end{abstract}

Kata Kunci : iLearning Education, Survey, Pengukuran, Efektivitas Pembelajaran,

\begin{abstract}
Raharja College is one of the Universities that applies a learning method that is quite different, that is, it does not only rely on conventional learning systems where the KBM (Teaching and Learning Activities) is carried out by students and lecturers face-to-face, but also applying e-learning methods. learning or better known as the iLearning Education learning system at Raharja College. In its implementation, several devices are used to support the learning system starting from iDu (iLearning Education) as a media for interaction between Students and Lecturers as well as the Use of iLearning Media (IME) as a media that accommodates learning activities through the iLearning Education method. Then during the course of this method several questions arise about how valid the system is for the quality of the assessment and effectiveness of learning methods where it is deemed necessary to apply a measuring instrument that can measure system validity towards the quality and effectiveness of learning methods at Raharja College especially in the Independent class Study IL101A and IL101C. By using a descriptive method with a research survey approach conducted where the survey conducted found a problem solving that is the procurement of a measuring instrument that can later display historical data with certain categories in terms of the effectiveness of learning can be proven empirically through accurate data.
\end{abstract}

Keyword: iLearning Education, Survey, Measurement, Learning Effectiveness, 


\section{PENDAHULUAN}

Perguruan Tinggi Raharja, sebagai lembaga pendidikan tinggi yang memberikan gelar akademik pada bidang IT, merupakan tempat pengembangan gagasan dan pengetahuan, persemaian nilai-nilai kehidupan, dan perkembangan peradaban. Perguruan Tinggi Raharja dituntut menghasilkan lulusan terbaik yang berguna bagi masyarakat, menciptakan berbagai produk bagi pemecahan masalah kemanusiaan, mendiseminasikan hasil-hasil riset dan output lain yang pada akhirnya dapat menyumbang pada perkembangan pengetahuan dan kearifan umat manusia.

Permasalahan yang dihadapi saat ini adalah, Bagaimana agar Dosen dapat menerapkan model pembelajaran iLearning pada kelas Independent Study dan Bagaimana agar Mahasiswa dapat memanfaatkan model pembelajaran iLearning pada kelas Independent Study dengan antusias tinggi, sehingga mendapatkan ilmu yang bermanfaat.

Perkembangan teknologi informasi dan komunikasi yang sangat pesat mendorong berbagai lembaga pendidikan untuk memanfaatkan konsep dan desain sistem e-learning untuk meningkatkan efektivitas dan fleksibilitas pembelajaran. Dalam penelitian ini, penggunaan sistem informasi berbasis pendidikan akan digunakan sebagian besar oleh Mahasiswa dan Dosen untuk berinteraksi dalam dunia maya. Sehingga baik visi maupun misi perguruan tinggi dapat terealisasi, dengan adanya sistem informasi ini. Mahasiswa yang kurang mampu mengikuti pelajaran akan terbentuk dengan adanya sistem informasi ini. Sehingga dalam pengembangan sistem informasi, baik Mahasiswa dan Dosen perlu secara proaktif untuk dilibatkan dengan keputusan strategis dalam implementasi aplikasi ini. Dengan kata lain diperlukan partisipasi aktif dari para pengguna baik Mahasiswa maupun Dosen, agar nantinya sistem yang dikembangkan dapat berjalan secara efektif.

interaktif dalam kehidupan sehari-hari. iLearning mengorganisir aktivitas peserta didik untuk bisa berkesinambungan dengan belajar, bermain, bekerja, dan berdoa. Pengembangan iLearning dapat menciptakan integritas yang baik untuk sistem pembelajaran modern di masa depan. Dengan demikian iLearning merupakan leaders yang baik untuk pendidik maupun peserta didik untuk mendapatkan informasi yang akurat dan relevan yang bisa didapat dimana saja, kapan saja disaat kita belajar, bermain, berdoa maupun bekerja. Melakukan 4B hanya dengan satu sentuhan tangan.

Oleh karena itu, dari uraian di atas maka dibutuhkan sebuah pengukuran dalam rangka implementasi sistem iLearning Education dan iLearning Media agar dapat diketahui validitas dari sistem tersebut terhadap kualitas penilaian dan efektivitas metode pembelajaran yang termasuk ke dalam objek penelitian tersebut.

\section{METODOLOGI PENELITIAN}

Metodologi atau tahapan penelitian diperlukan sebagai kerangka dan panduan proses penelitian, sehingga rangkaian proses penelitian dapat dilakukan secara terarah, teratur dan sistematis 


\section{Metode Populasi dan Sampel}

Hubungan antara sampel dengan populasi adalah analisis data sampel menghasilkan statistik sampel yang digunakan untuk mengestimasi parameter populasinya. Selain itu, parameter adalah ukuran deskripsi numeris yang dihitung dari pengukuran populasi. Statistik sampel digunakan untuk membuat inferensi mengenai parameter populasinya (Zainal A Hasibuan, 2007:74).

\section{A. Populasi}

Populasi adalah wilayah generalisasi yang terdiri atas obyek atau subyek yang mempunyai kualitas dan karakteristik tertentu yang ditetapkan oleh peneliti untuk dipelajari dan kemudian ditarik kesimpulannya (Sugiyono 2012:90).

populasi bukan hanya orang, tetapi juga objek dan benda- benda alam yang lain. Populasi juga bukan sekedar jumlah yang ada pada obyek atau subyek yang dipelajari, tetapi meliputi seluruh karakteristik atau sifat yang dimiliki oleh subyek atau obyek itu.

Populasi dalam penelitian ini adalah seluruh Mahasiswa kelas matakuliah Independent Study Perguruan Tinggi Raharja, adapun data Mahasiswa kelas matakuliah Independent Study IL101A saat ini pada saat proses perkuliahan semester genap Tahun Akademik 2015/2016 total Mahasiswa sejumlah 37 Mahasiswa yang memanfaatkan iDu, Rinfo dan iMe dalam sistem pembelajarannya.

\section{B. Sampel}

Teknik Sampling adalah merupakan teknik pengambilan sampel yang digunakan dalam penelitian (Soesatyo 2013). Penentuan pengambilan sampel pada penelitian ini ditentukan dengan menggunakan teknik Penarikan sampel secara acak atau random (Probability Sampling) dengan Jenis Sampling Acak Sederhana (Simple Random Sampling). Metode SRS (Simple Random Sampling) adalah metode yang digunakan untuk memilih sampel dari populasi dengan cara sedemikian rupa sehingga setiap anggota populasi mempunyai peluang yang sama besar untuk diambil sebagai sampel. Seluruh anggota populasi menjadi anggota dari kerangka sampel. SRS biasa digunakan jika populasi bersifat homogen. Cara pengambilan sampel bisa dilakukan dengan pengembalian atau tanpa pengembalian (Nurhayati 2008).

Pengambilan sampel menggunakan "Simple Random Sampling". Pengambilan anggota sampel dari populasi Mahasiswa/i kelas mata kuliah Independent Study IL101A, IL101B, dan IL101C Jumlah anggota sampel total 
ditentukan melalui rumus Slovin, adapun rumus tersebut adalah sebagai berikut :

Keterangan :

$\mathrm{n}=$ Sampel

$\mathrm{N}=$ Populasi

$\mathrm{e}=$ Nilai kritis/batas ketelitian yang diinginkan (dalam penelitian ini dipilih 10\%)

Berdasarkan populasi yang ada, maka perhitungan jumlah sampel yang diambil untuk penelitian ini adalah sebagai berikut :

Pada penelitian ini pengambilan sampel dengan menggunakan Simple Random Sampling, yaitu berjumlah 27 orang Mahasiswa kelas Independent Study IL101A, IL101B, dan IL101C.

\section{Metode Instrumen Penelitian}

Instrumen pengujian dalam penelitian ini yakni berupa kuesioner yang akan digunakan untuk melakukan pengukuran dengan tujuan menghasilkan data kuantitatif yang akurat. Instrumen atau alat pengumpulan datanya pun disebut angket dan berisi sejumlah pertanyaan atau pernyataan yang harus dijawab atas respons oleh responden. Kuesioner yang digunakan pada penelitian ini adalah kuesioner tertutup. Adanya pertanyaan atau pernyataan yang telah disusun secara terstruktur. Selain ada pertanyaan pokok atau pertanyaan utama, ada anak pertanyaan telah memiliki alternatif jawaban yang dipilih oleh responden. Dimana responden diminta menjawab pertanyaan atau pernyataan dan menjawab dengan memilih dari sejumlah alternatif. Keuntungan bentuk tertutup ialah mudah diselesaikan, mudah dianalisis dan mampu memberikan jangkauan jawaban yang pasti.

Setelah data terkumpul yang diperoleh melalui instrumen yang dipilih, perlu dikaji validitas dengan cara melakukan penelitian pada sampel yang dipilih dengan Metode Skala Likert. Dengan menggunakan Skala Likert, variabel yang akan diukur dijabarkan menjadi dimensi, lalu dimensi dijabarkan menjadi sub variabel dan subvariabel dijabarkan menjadi indikator yang dapat diukur. Akhirnya indikatorindikator yang terukur dapat menjadi titik tolak untuk membuat item instrumen berupa pernyataan atau pertanyaan yang perlu dijawab oleh responden. setiap jawaban dihubungkan dengan bentuk pernyataan atau dukungan sikap yang diungkapkan dengan kata-kata sebagai berikut :

Pertanyaan atau pernyataan positif :

Sangat Setuju $(\mathrm{SS})=$ Nilai 5

Setuju $(S)=$ Nilai 4

Cukup Setuju $(\mathrm{CS})=$ Nilai 3

Tidak Setuju $(\mathrm{TS})=$ Nilai 2

Sangat Tidak Setuju $($ STS $)=$ Nilai 1 
Pertanyaan atau pernyataan negatif :

Sangat Setuju $($ SS $)=$ Nilai 1

Setuju $(S)=$ Nilai 2

Cukup Setuju $(\mathrm{CS})=$ Nilai 3

Tidak Setuju $(\mathrm{TS})=$ Nilai 4

Sangat Tidak Setuju $($ STS $)=$ Nilai 5

Dalam penelitian ini penulis juga menggunakan pengukuran dengan instrumen penelitian adalah suatu alat yang dapat digunakan untuk memperoleh, mengolah, dan menginterpretasikan informasi yang diperoleh dari para responden yang dilakukan dengan menggunakan pola ukur yang sama.

\section{Literatur Review}

Berikut ini adalah beberapa literatur perbandingan pembahasan yang digunakan dalam penelitian ini :

1. Penelitian yang dilakukan oleh Untung Rahardja, Fery Sudarto dan Linda Octavia dari Perguruan Tinggi raharja, Indonesia pada tahun 2013 yang berjudul “ iDuHelp!” : Penerapan Campus Service Sistem iDuHelp! Dalam Mendukung Kegiatan iLearning Education ( IDU ) Pada Perguruan Tinggi". Penelitian ini menjelaskan sebuah pelayanan informasi secara Online dan Offline. Dengan adanya sistem penerapan campus service system iDuHelp! Untuk menunjang kegiatan iLearning Education pada Perguruan Tinggi ini diharapkan bagi calon Mahasiswa tidak kesulitan untuk mengakses informasi mengenai hal-hal yang bersangkutan dengan penerimaan Mahasiswa baru dan diharapkan juga dengan adanya iDuHelp!, calon Mahasiswa tidak kesulitan untuk daftar dimanapun dan kapanpun, selain itu dapat mengetahui fasilitas dan news apa saja yang dimiliki oleh kampus tersebut tanpa harus mengunjungi kampus tersebut.

2. Penelitian yang dilakukan oleh A. Saefullah, P. Siahaan dan I. M. Sari pada tahun 2013 dengan judul "Hubungan antara Sikap Kemandirian Belajar dan Prestasi Belajar Siswa Kelas X pada Pembelajaran Fisika Berbasis Portofolio" menjelaskan bahwa sikap kemandirian belajar yang dimiliki siswa sudah membaik, prestasi belajar yang diraih oleh siswa juga membaik sehingga terdapat hubungan yang searah antara sikap kemandirian belajar dan prestasi belajar siswa, semakin baik sikap kemandirian belajar yang dimiliki siswa, maka akan semakin baik pula prestasi belajar yang diraih.

3. "Pemanfaatan E-Learning Sebagai Media Pembelajaran Pada Pendidikan Tinggi Jarak Jauh [Timbul, 2011]" Menjelaskan bahwa Melalui e-learning proses belajar mengajar dapat dilakukan tanpa adanya tatap muka antara pengajar dan peserta didik dan tidak lagi dibatasi oleh waktu dan tempat. E-learning menjadi salah satu solusi bagi permasalahan dunia pendidikan yang semakin sibuk dengan berbagai layanan yang menawarkan fleksibilitas dan mobilitas yang tinggi. Perbedaan 
dengan penelitian ini adalah tidak adanya pengaruh motivasi pembelajarannya pada Mahasiswa.

\section{PEMBAHASAN}

\section{1. iLearning}

Pada dasarnya istilah iLearning (Integrated Learning) berasal dari pemikiran perkembangan Teknologi iPad di Perguruan Tinggi Raharja, Belajar, Bermain, Berdoa dan Bekerja menurut Rahardja (2012). Pembelajaran secara efisien, praktis dan menyenangkan sehingga membuat Mahasiswa/i menjadi lebih menarik dan semangat dalam belajar dengan didukung teknologi yang mempermudah jangkauan Mahasiswa/i dalam melakukan interaksi. Dengan demikian, pengertian terhadap keempat unsurunsur pokok ini akan sangat membantu dalam memahami iLearning.

Istilah iLearning mengandung pengertian bahwa: "Merupakan suatu metode sistem pembelajaran yang sedang disiapkan oleh Perguruan Tinggi Raharja dengan upaya memberikan pelayanan prima kepada seluruh Mahasiswa/i dalam bentuk service excellence sebagai kampus unggulan". "Perguruan Tinggi Raharja dalam mengembangkan konsep proses pembelajaran berbasis multimedia secara online yang dikemas secara entertainment, sehingga menghadirkan konsep Interactive Education Learning yang menyentuh dalam proses belajar mengajar kepada seluruh civitas akademika dan secara terus menerus melakukan perbaikan (continuous improvement) menuju kesempurnaan dalam materi bahan ajar yang selalu berkembang seiring dengan kemajuan dan perkembangan teknologi”.

Henny Lim (2007:159) dalam penelitiannya mengungkapkan bahwa manfaat positif yang dapat diambil dari e-Learning adalah meningkatkan independensi eLearner dalam belajar. E-Learning sendiri mempunyai peranan yang cukup penting, antara lain meningkatkan pemerataan pendidikan, meningkatkan wawasan, mengatasi kekurangan tenaga pendidikan, dan meningkatkan efisiensi.

Untung Rahardja et.al. (2011:71) menjelaskan bahwa sistem iLearning (integrated Learning) atau dalam bahasa indonesia disebut sistem pembelajaran terpadu yang diterapkan merupakan salah satu bentuk untuk meningkatkan mutu menuju suatu pendidikan yang modern dan berkualitas.

\section{Pembelajaran}

Belajar merupakan suatu aktivitas atau psikis, yang berlangsung dalam interaksi aktif dengan lingkungannya yang menghasilkan sejumlah perubahan dalam pengetahuan - pengetahuan, keterampilan, nilai dan sikap yang bersifat konstan dan menetap (W. S. Winkel, 2009: 59).

pembelajaran menurut Martinis Yamin dan Bansu I. Ansari (2009) yaitu 
kemampuan dalam mengelola secara operasional dan efisien terhadap komponen komponen yang berkaitan dengan pembelajaran, komponen- komponen tersebut antara lain Dosen, Mahasiswa, sarana prasarana dan proses pembelajaran. Di dalam pembelajaran terjadi proses interaksi antara pendidik dengan peserta didik dan sumber belajar pada suatu lingkungan belajar untuk mencapai tujuan pembelajaran.

Berdasarkan berbagai pendapat di atas dapat disimpulkan bahwa belajar merupakan suatu proses memperoleh pengetahuan dan pengalaman dalam wujud perubahan tingkah laku dan kemampuan bereaksi yang relatif permanen atau menetap karena adanya interaksi individu dengan lingkungannya. Perubahan- perubahan dalam belajar tidak hanya berkaitan dengan penambahan ilmu pengetahuan, tetapi juga berbentuk kecakapan, sikap, pengertian, harga diri, minat, watak, penyesuaian diri dan sebagainya. Perubahan tersebut dapat berupa suatu hasil yang baru sama sekali atau penyempurnaan terhadap hasil yang telah diperoleh.

\section{Penilaian}

Menurut Nitko dalam David A Jacobsen (2009: 290) "Penilaian kelas (classroom assessment) mencakup semua proses yang dilibatkan dalam membuat keputusan keputusan tentang kemajuan pembelajaran Mahasiswa". Dosen mengumpulkan informasi melalui penilaian formal dan nonformal. Penilaian nonformal merupakan proses pengumpulan informasi yang insidental tentang kemajuan pembelajaran dan proses pengambilan keputusan-keputusan berdasarkan informasi tersebut. Sebaliknya, penilaian formal merupakan proses pengumpulan informasi secara sistematis dan proses pembuatan keputusan tentang kemajuan pembelajaran (David A Jacobsen et.al., 2009: 291).

Dalam dasar pemikiran penilaian biasanya didapatkan berdasarkan tes-tes untuk mengukur sejauh mana kemampuan dan mengetahui hasil belajar Mahasiswa. Menurut Sudaryono et.al. (2013: 63) menyatakan bahwa tes merupakan himpunan pertanyaan yang harus dijawab, harus ditanggapi, atau tugas yang harus dilaksanakan oleh orang yang dites. Tes digunakan untuk mengukur sejauh mana seorang siswa telah menguasai pelajaran yang disampaikan terutama meliputi aspek pengetahuan dan keterampilan.

\section{IMPLEMENTASI}

\section{Perancangan Kuesioner}

Kuesioner yang didesain merupakan hasil dari sisipan atau embed dari Rinfo Forms yang merupakan bagian dari Google Apps. 


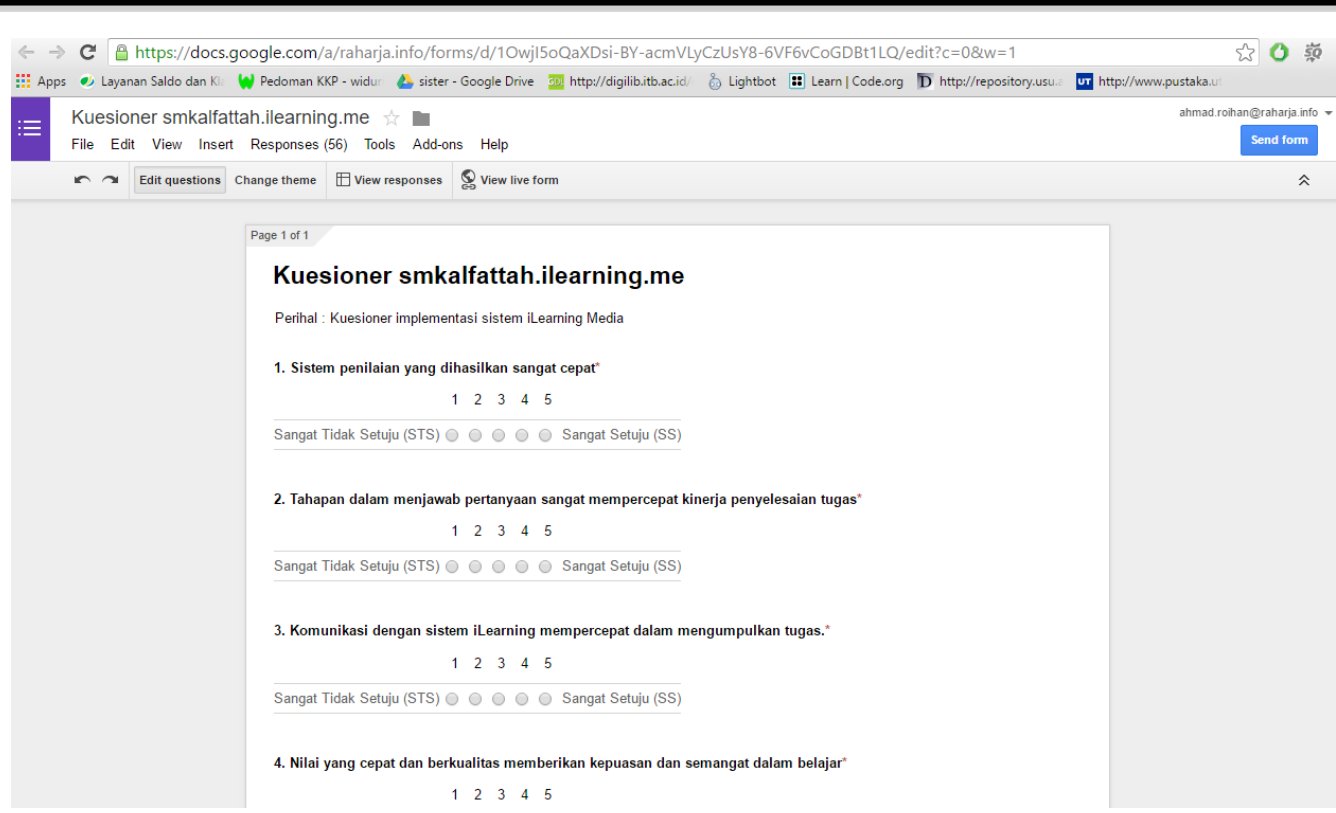

Gambar 1. Desain Kuesioner dalam Rinfo Forms

\section{Pengolahan Analisis Data}

Sebagaimana tujuan penelitian yang tercantum pada BAB I, bahwa penelitian ini dilakukan untuk mencari kejelasan tentang Pengaruh Model Pembelajaran iLearning Pada Kelas Independent Study Terhadap Peningkatan Motivasi Pembelajaran dan Kualitas Penilaian. Untuk mengetahui apakah terdapat pengaruh positif antara variabel bebas (independent variable) dan variabel terikat (dependent variable) yang dipilih dalam penelitian ini, sekaligus memperoleh data kuantitatif. Peneliti menggunakan daftar pertanyaan yang diajukan kepada 100 responden sebanyak 30 pernyataan. Setiap pernyataan yang diajukan mempunyai kemungkinan 5 (lima) jawaban, dengan nilai 1 (satu) sampai dengan 5 (lima). Dengan demikian, nilai maksimal untuk setiap responden sebanyak 150 (30 butir soal x 5 poin), sedangkan nilai minimal sebanyak 30 (30 butir soal x 1 poin).

Mengenai penyebaran jumlah pernyataan antar variabel, variabel Pengaruh Model Pembelajaran iLearning Pada Kelas Independent Study $\left(\mathrm{X}_{1}\right)$ meliputi pernyataan nomor 1, 2, 3, 4, 5, 6, 7, 8, 26, dan 27, variabel Peningkatan Motivasi Pembelajaran $\left(\mathrm{X}_{2}\right)$ meliputi pernyataan nomor 9 , 10, 11, 12, 13, 14, 15, 16, 28, dan 29, serta variabel Kualitas Penilaian (Y) meliputi pernyataan nomor 17, 18, 19, 20 , $21,22,23,24,25$, dan 30 .

Penelitian ini dilakukan pengujian validitas dan reliabilitas dengan menggunakan aplikasi IBM SPSS Statistik 23. Setelah dilakukan pengujian maka didapatkan hasil pengujian dari setiap variabel yaitu Pengaruh Model Pembelajaran iLearning Pada Kelas Independent Study $\left(\mathrm{X}_{1}\right)$, Peningkatan Motivasi Pembelajaran $\left(\mathrm{X}_{2}\right)$, dan variabel Kualitas Penilaian (Y). Dari keseluruhan butir soal yaitu 30 yang diberikan kepada responden ada beberapa soal yang dinyatakan tidak valid karena $r$ 
hitung < dari nilai $\mathrm{r}$ tabelnya dimana nilai $\mathrm{df}=\mathrm{N}-2$, yaitu jumlah responden $\mathrm{df}=100$ - $2=98$. Berdasarkan nilai $\mathrm{r}$ tabel tingkat signifikansi 2 arah $0,05 / 2=0,025$ dimana nilai $r$ tabel untuk df $98=0,1966$. Adapun hasil data yang telah diolah adalah valid semua. Hasil angket dan rekapitulasi jumlah data terlampir.

\section{Analisis Variabel}

Dari data rekapitulasi jumlah hasil angket, jika dimasukkan ke program SPSS dan dibuat deskripsi statistik serta tabel frekuensinya menghasilkan data :

\section{Pengaruh Pembelajaran iLearning Pada Kelas Independent Study $\left(\mathrm{X}_{1}\right)$}

Statistik data untuk variabel $\mathrm{X}_{1}$ (Pengaruh Model Pembelajaran iLearning Pada Kelas Independent Study) tercantum pada tabel 4.2 berikut ini :

Tabel 1. Statistik Data Variabel $X_{1}$ (Pengaruh Model Pembelajaran iLearning Pada Kelas Independent Study)

\begin{tabular}{|l|l|}
\hline Keterangan & Nilai \\
\hline Mean & 41,27 \\
\hline Median & 41,00 \\
\hline Mode & 38 \\
\hline Std. Deviation & 4,526 \\
\hline Variance & 20,482 \\
\hline Range & 25 \\
\hline Minimum & 25 \\
\hline Maximum & 50 \\
\hline Percentiles : & 37,10 \\
$10 \%$ & 38,20 \\
$20 \%$ & 38,00 \\
$25 \%$ & 39,00 \\
$30 \%$ & 40,00 \\
$40 \%$ & 41,00 \\
$50 \%$ & 42,00 \\
$60 \%$ & 44,00 \\
$70 \%$ & 45,00 \\
$75 \%$ & \\
\hline
\end{tabular}




\begin{tabular}{|l|l|}
\hline $80 \%$ & 46,00 \\
$90 \%$ & 48,00 \\
\hline
\end{tabular}

Untuk variabel Pengaruh Model Pembelajaran iLearning Pada Kelas Independent Study, dari 100 data yang terproses, mean (nilai rata-rata) untuk variabel ini tercantum 41,27. Median (titik tengah data) jika semua diurutkan dari yang terkecil sampai dengan yang terbesar tercantum 41,00. Nilai yang paling banyak muncul (mode) sebesar 48, standar deviasi tercantum 4,526, dan varian (kelipatan/kuadrat) dari standar deviasi adalah 20,482 (4,526 ${ }^{2}$ ) merupakan angka ini menggambarkan variasi data yang dimiliki.

Selain itu, ada minimum, maksimum, dan range. Data minimum adalah data tingkat terendah responden, yakni 25, sedangkan maksimum adalah data tingkat tertinggi responden, yakni 50, dan range adalah selisih maksimum dan minimum, yakni 25 (50-25).

Terakhir, tercantum percentiles atau angka persentil. Artinya, rata-rata 10\% responden memiliki pengaruh terhadap Pengaruh Model Pembelajaran iLearning Pada Kelas Independent Study dengan nilai dibawah 37,10, rata-rata $20 \%$ responden memiliki tingkat pengaruh terhadap Pengaruh Model Pembelajaran iLearning Pada Kelas Independent Study dengan nilai dibawah 38,00 , rata-rata $25 \%$ responden memiliki tingkat pengaruh terhadap Pengaruh Model Pembelajaran iLearning Pada Kelas Independent Study dengan nilai dibawah 38,00, rata-rata $30 \%$ responden memiliki tingkat pengaruh terhadap Pengaruh Model Pembelajaran iLearning Pada Kelas Independent Study dengan nilai dibawah 39,00, rata-rata 40\% responden memiliki tingkat pengaruh terhadap Pengaruh Model Pembelajaran iLearning Pada Kelas Independent Study dengan nilai dibawah 40,00, rata-rata 50\% responden memiliki tingkat pengaruh terhadap Pengaruh Model Pembelajaran iLearning Pada Kelas Independent Study dengan nilai dibawah 41,00 , rata-rata $60 \%$ responden memiliki tingkat pengaruh terhadap Pengaruh Model Pembelajaran iLearning Pada Kelas Independent Study dengan nilai dibawah 42,00, rata-rata $70 \%$ responden memiliki tingkat pengaruh terhadap Pengaruh Model Pembelajaran iLearning Pada Kelas Independent Study dengan nilai dibawah 44,00, rata-rata $75 \%$ responden memiliki tingkat pengaruh terhadap Pengaruh Model Pembelajaran iLearning Pada Kelas Independent Study dengan nilai dibawah 45,00, rata-rata $80 \%$ responden memiliki tingkat pengaruh terhadap Pengaruh Model Pembelajaran iLearning Pada Kelas Independent Study dengan nilai dibawah 46,00, dan rata- rata 90\% responden memiliki tingkat pengaruh terhadap Pengaruh Model Pembelajaran iLearning Pada Kelas Independent Study dengan nilai dibawah nilai 48,00.

\section{Peningkatan Pembelajaran $\left(\mathbf{X}_{2}\right)$}


Statistik data untuk variabel $\mathrm{X}_{2}$ (Peningkatan Pembelajaran) tercantum pada tabel 4.5 berikut ini :

Tabel 2. Statistik Data Variabel $\mathbf{X}_{2}$ (Peningkatan Motivasi Pembelajaran)

\begin{tabular}{|l|l|}
\hline Keterangan & Nilai \\
\hline Mean & 41,58 \\
\hline Median & 40,00 \\
\hline Mode & 38 \\
\hline Std. Deviation & 4,768 \\
\hline Variance & 22,731 \\
\hline Range & 23 \\
\hline Minimum & 27 \\
\hline Maximum & 50 \\
\hline Percentiles : & 38,00 \\
$10 \%$ & 38,00 \\
$20 \%$ & 38,00 \\
$25 \%$ & 38,00 \\
$30 \%$ & 49,00 \\
$40 \%$ & 40,00 \\
$50 \%$ & 42,00 \\
$60 \%$ & 45,00 \\
$70 \%$ & 46,75 \\
$75 \%$ & 48,00 \\
$80 \%$ & \\
$90 \%$ & 480 \\
\hline & \\
\hline & \\
\hline
\end{tabular}

Untuk variabel Peningkatan Motivasi Pembelajaran, dari 100 data yang terproses, mean (nilai rata-rata) untuk variabel ini tercantum 41,58. Median (titik tengah data) jika semua diurutkan dari yang terkecil sampai dengan yang terbesar tercantum 40,00. Nilai yang paling banyak muncul (mode) sebesar 38, standar deviasi tercantum 4,768, dan varian (kelipatan/kuadrat) dari standar deviasi adalah $22,731\left(4,768^{2}\right)$ merupakan angka ini menggambarkan variasi data yang dimiliki.

Selain itu, ada minimum, maksimum, dan range. Data minimum adalah data tingkat terendah responden yakni 27, sedangkan maksimum adalah data tingkat tertinggi responden, yakni 50, dan range adalah selisih maksimum dan minimum, yakni 23 (50-27). 
Terakhir, tercantum percentiles atau angka persentil. Artinya, rata-rata 10\% responden memiliki pengaruh terhadap Peningkatan Motivasi Pembelajaran dengan nilai dibawah 38,00, rata-rata $20 \%$ responden memiliki tingkat pengaruh terhadap Peningkatan Motivasi Pembelajaran dengan nilai dibawah 41,20, ratarata $25 \%$ responden memiliki tingkat pengaruh terhadap Peningkatan Motivasi Pembelajaran dengan nilai dibawah 38,00, rata-rata $30 \%$ responden memiliki tingkat pengaruh terhadap Peningkatan Motivasi Pembelajaran dengan nilai dibawah 38,00, rata-rata $40 \%$ responden memiliki tingkat pengaruh terhadap Peningkatan Motivasi Pembelajaran dengan nilai dibawah 38,00, rata-rata 50\% responden memiliki tingkat pengaruh terhadap Peningkatan Motivasi Pembelajaran dengan nilai dibawah 40,00, rata-rata $60 \%$ responden memiliki tingkat pengaruh terhadap Peningkatan Motivasi Pembelajaran dengan nilai dibawah 42,00, rata-rata $70 \%$ responden memiliki tingkat pengaruh terhadap Peningkatan Motivasi Pembelajaran dengan nilai dibawah 45,00, rata-rata 75\% responden memiliki tingkat pengaruh terhadap Peningkatan Motivasi Pembelajaran dengan nilai dibawah 46,75, rata-rata $80 \%$ responden memiliki tingkat pengaruh terhadap Peningkatan Motivasi Pembelajaran dengan nilai dibawah 47,00, dan rata- rata 90\% responden memiliki tingkat pengaruh terhadap Peningkatan Motivasi Pembelajaran dengan nilai dibawah nilai 48,00.

\section{Peningkatan Penilaian (Y)}

Statistik data untuk variabel Y (Kualitas Penilaian) tercantum pada tabel 4.8 berikut ini :

Tabel 3. Statistik Data Variabel Y (Kualitas Penilaian)

\begin{tabular}{|l|l|}
\hline Keterangan & Nilai \\
\hline Mean & 42,07 \\
\hline Median & 45,00 \\
\hline Mode & 39 \\
\hline Std. Deviation & 4,613 \\
\hline Variance & 21,278 \\
\hline Range & 21 \\
\hline Minimum & 29 \\
\hline Maximum & 50 \\
\hline Percentiles : & \\
\hline
\end{tabular}




\begin{tabular}{|l|l|}
\hline $10 \%$ & 38,00 \\
$20 \%$ & 39,00 \\
$25 \%$ & 39,00 \\
$30 \%$ & 39,00 \\
$40 \%$ & 40,00 \\
$50 \%$ & 40,00 \\
$60 \%$ & 41,60 \\
$70 \%$ & 44,00 \\
$75 \%$ & 46,75 \\
$80 \%$ & 48,80 \\
$90 \%$ & 49,00 \\
\hline
\end{tabular}

Untuk variabel Y (Kualitas Penilaian), dari 100 data yang terproses, mean (nilai rata-rata) untuk variabel ini tercantum 42,07. Median (titik tengah data) jika semua diurutkan dari yang terkecil sampai dengan yang terbesar tercantum 45,00. Nilai yang paling banyak muncul (mode) sebesar 39, standar deviasi tercantum 4,613, dan varian (kelipatan/kuadrat) dari standar deviasi adalah $21,278\left(4,613^{2}\right)$ merupakan angka ini menggambarkan variasi data yang dimiliki.

Selain itu, ada minimum, maksimum, dan range. Data minimum adalah data tingkat terendah responden yakni 29, sedangkan maksimum adalah data tingkat tertinggi responden, yakni 50, dan range adalah selisih maksimum dan minimum, yakni 21 (50-29).

Terakhir, tercantum percentiles atau angka persentil. Artinya, rata-rata $10 \%$ responden memiliki pengaruh terhadap Kualitas Penilaian dengan nilai dibawah 38,00, rata-rata $20 \%$ responden memiliki tingkat pengaruh terhadap Kualitas Penilaian dengan nilai dibawah 39,00, rata-rata 25\% responden memiliki tingkat pengaruh terhadap Kualitas Penilaian dengan nilai dibawah 39,00, ratarata 30\% responden memiliki tingkat pengaruh terhadap Kualitas Penilaian dengan nilai dibawah 39,00, rata-rata $40 \%$ responden memiliki tingkat pengaruh terhadap Kualitas Penilaian dengan nilai dibawah 40,00, rata-rata 50\% responden memiliki tingkat pengaruh terhadap Kualitas Penilaian dengan nilai dibawah 40,00, rata-rata $60 \%$ responden memiliki tingkat pengaruh terhadap Kualitas Penilaian dengan nilai dibawah 41,60 , rata-rata $70 \%$ responden memiliki tingkat pengaruh terhadap Kualitas Penilaian dengan nilai dibawah 44,00, rata-rata $75 \%$ responden memiliki tingkat pengaruh terhadap Kualitas Penilaian dengan nilai dibawah 46,75, rata-rata $80 \%$ responden memiliki tingkat pengaruh terhadap Kualitas Penilaian dengan nilai dibawah 48,80, dan rata- rata $90 \%$ responden memiliki tingkat pengaruh terhadap Kualitas Penilaian dengan nilai dibawah nilai 49,00 . 


\section{KESIMPULAN}

Dari uraian pembahasan pada bab sebelumnya maka kesimpulan dari penelitian ini adalah sebagai berikut:

1. Dengan menggunakan iLearning Education (iDu) disertai konsep dan perangkat business intelligence dengan dashboard pada sistem tersebut, dapat dinyatakan bahwa penilaian kepada Mahasiswa lebih objektif baik dari Dosen kepada Mahasiswa maupun sebaliknya dapat diukur dan membuktikan bahwa meningkatkan kualitas penilaian.

2. Sistem yang diimplementasikan dapat mengukur dari efektivitas pembelajaran dengan dibuktikan secara empiris melalui data kuesioner yang valid dan reliabel. Baik dari segi dimensi Readiness, Accurate, dan Timeliness.

\section{SARAN}

Berdasarkan pembahasan tentang implementasi sistem ini, dapat disampaikan beberapa saran untuk digunakan pada penelitian selanjutnya,

1. Dengan model data mart yang ada, dapat dilakukan pengembangan lebih lanjut dengan melakukan penerapan data mining yang bisa digunakan untuk memprediksi probabilitas dari keaktifan pengguna dalam mengerjakan tugas sehingga dapat digunakan untuk keperluan forecasting.

2. Hasil implementasi data mart dan OLAP ini dapat dikembangkan ke model business intelligence yaitu data warehouse, dengan menggabungkan seluruh database yang ada dalam organisasi dapat dijadikan landasan utama untuk menunjang keputusan management dalam mengelola organisasi tersebut.

\section{DAFTAR PUSTAKA}

[1] Hasibuan, Zainal A, 2007. Metodologi Penelitian pada Bidang Ilmu Komputer dan Teknologi Informasi. Depok, Fakultas Ilmu Komputer Universitas Indonesia.

[2] Rahardja, Untung, Desrianti, Dewi, Immaniar, Mawadah, Siti, 2011. iBooks Standardisation and Good Practice for Effective Education Methods In Support of iLearning. Tangerang, CCIT Journal Vol. 5 STMIK Raharja.

[3] Sudaryono, 2014a. Classroom Action Research. Jakarta Pusat: Lentera Ilmu Cendekia.

[4] Sudaryono, 2014b. Leadership: Teori dan Praktek Kepemimpinan. Jakarta Pusat, Lentera Ilmu Cendekia.

[5.] Jacobsen, David A, Eggen, Paul, Kauchak, Donald, 2009. Methods For Teaching: Metode-metode Pengajaran Meningkatkan Belajar Siswa TK-SMA edisi ke-8. Yogyakarta: Pustaka Pelajar.

[6] Sudaryono, Margono, Gaguk, Rahayu, Wardani, 2013. Pengembangan Instrumen Penelitian Pendidikan. Yogyakarta: Graha Ilmu. 